\title{
Effects of carbon to nitrogen ratio on the performance and stability of aerobic granular sludge
}

\author{
HyunGu Kim', JiTae $\mathrm{Kim}^{2}$, DaeHee $\mathrm{Ahn}^{1,3^{+}}$ \\ ${ }^{1}$ BlueBank Co., Ltd., Business Incubator Center, Myongji University, Yongin 17058, Republic of Korea \\ ${ }^{2}$ Department of Environmental and Energy Engineering, Kyonggi University, Suwon 16227, Republic of Korea \\ ${ }^{3}$ Department of Environmental Engineering and Energy, Myongji University, Yongin 17058, Republic of Korea
}

\begin{abstract}
The purpose of this study was to assess the nutrient salts removal efficiency and stability of the aerobic granular sludge (AGS) by change in $\mathrm{C} / \mathrm{N}$ (carbon to nitrogen) ratio. The laboratory-scale experiments were performed to analyze the removal efficiencies for organic matter and contents of nitrogen, MLSS, sludge volume index, and extracellular polymeric substances (EPS) under C/N ratio conditions of 5.0, 10.0, 15.0, and 20.0. The microorganisms were observed using optical microscope and the microbial communities were analyzed using pyrosequencing. The increase in $\mathrm{C} / \mathrm{N}$ ratio from 5.0 to 20.0 increased the organic matter and nitrogen removal efficiency to 95.9 and $79.1 \%$, respectively. For the EPS contents, an influencing factor of granule stability, the polysaccharides to protein (PS/PN) ratio increased from 0.55 to 0.79 . For the microbial community, the Thauera was the most common genus in ending phase occupying $63.7 \%$. This microorganism is regarded as one contributing to organic matter degradation and improved production of EPS including AGS of microorganism, thus, may be an explanation of the results of this study such as increase in organic material in AGS and improvement of denitrification efficiency and contents of EPS with increase in $\mathrm{C} / \mathrm{N}$ ratio.
\end{abstract}

Keywords: Aerobic granular sludge (AGS), Carbon to nitrogen ratio, Organic matter, Nitrogen, Microbial community

\section{Introduction}

The aerobic granulation is a self-immobilization process in which the loose biomass is converted into high-density compacted granule [1-4]. The aerobic granular sludge (AGS), compared to traditional activated sludge, has more excellent characteristics in terms of regular shape and compact structure, sedimentation, biomass accumulation, resistance to toxic compounds and high organic load, and removal efficiency of nutrient salts [5-8]. These made the AGS technique made to be widely used in treatments of high-load industrial wastewater as well as sewage [9-12]. The stability of AGS is the most important issue in applying AGS-based process in various fields and is related many factors including the composition of influent wastewater, carbon to nitrogen $(\mathrm{C} / \mathrm{N})$ ratio, food to microorganisms (F/M) ratio, composition of extracellular polymeric substances (EPS), and rate and temperature of aeration [4, 8, 13-17], among which, the $\mathrm{C} / \mathrm{N}$ ratio of influent water is one of the most important factors for the growth of microorganism and bio- degradation of nutrient salt [13, 18-20]. The application of AGS system, for example, into the treatment of wastewater treatment where the variance in wastewater is high was reported to be an important factor in decreased stability, degradation of granule and the growth of filamentous fungus [21-24]. Since the EPS degraded by microorganism and contributing to formation and stability of AGS are mainly composed of protein (PN) and polysaccharides (PS), the stability of granule is affected by change in EPS concentration and PS/PN ratio due to change in $\mathrm{C} / \mathrm{N}$ ratio [25-28].

Mo et al. [29] analyzed the nutrient salts removal efficiency by operating the pilot plants of AGS-based sequencing batch process with capacity of 225 ton/day reported that the average $\mathrm{C} / \mathrm{N}$ ratio was about 3.1 and the nitrogen removal efficiency decreased when the $\mathrm{C} / \mathrm{N}$ ratio is under 2.0. Yae et al. [30] reported that, in the environment of average $\mathrm{C} / \mathrm{N}$ ratio of 4.5 , the stable operation of AGS-based process is possible by controlling variable operation conditions. Table S1 compares the AGS stability and pollutant removal efficiency by $\mathrm{C} / \mathrm{N}$ ratio [23, 24, 29-31]. This test was, how-
This is an Open Access article distributed under the terms of the Creative Commons Attribution Non-Commercial License (http://creativecommons.org/licenses/by-nc/3.0/) which permits unrestricted non-commercial use, distribution, and reproduction in any medium, provided the original work is properly cited.

Copyright (C) 2021 Korean Society of Environmental Engineers
Received July 08, 2019 Accepted February 18, 2020

${ }^{\dagger}$ Corresponding author

Email: dhahn@mju.ac.kr

Tel: +82-31-321-5901 Fax: +82-505-300-5901

ORCID: 0000-0002-6031-3610 
ever, performed in a restricted condition, and the further studies applying variant $\mathrm{C} / \mathrm{N}$ ratio are necessary to achieve more accurate understandings of pollutant removal efficiency and stability mechanism of AGS by change in $\mathrm{C} / \mathrm{N}$ ratio. The purpose of this study was, accordingly, to assess the effects of change in $\mathrm{C} / \mathrm{N}$ ratio on the pollutant removal efficiency of AGS and stability of granule. As of 2017, the $\mathrm{C} / \mathrm{N}$ ratio of domestic influent sewage is maintained in the range of 2.5-5.7 [32]. In addition, $\mathrm{C} / \mathrm{N}$ ratio of domestic influent wastewater is maintained in the range of 6.1-20.9 [33]. Therefore, influent $\mathrm{C} / \mathrm{N}$ ratio conditions of this study are to be subdivided from minimum 5.0 to maximum 20.0. For the purpose, the sequencing batch process was applied and the organic materials and nitrogen removal efficiency by change in $\mathrm{C} / \mathrm{N}$ ratio were measured. This study intended to contribute to this field by providing detail information collected by monitoring physical characteristics and contents and composition of EPS for the stability test of AGS and analyzing the effect on the change in microorganism population.

\section{Material and Methods}

\subsection{Synthetic Wastewater}

The influent wastewater used in study was synthesized to satisfy the prescribed $\mathrm{C} / \mathrm{N}$ ratios. The organic material, ammonias nitrogen, and alkaline were prepared using $\mathrm{CH}_{3} \mathrm{COONa} \cdot 3 \mathrm{H}_{2} \mathrm{O}, \mathrm{NH}_{4} \mathrm{Cl}$, and $\mathrm{NaHCO}_{3}$ (SAMCHUN Chemical, Korea). The $\mathrm{C} / \mathrm{N}$ ratio was set to increase gradually from 5.0, to 10.0, 15.0, and 20.0 by fixing the nitrogen concentration as $25 \mathrm{mg} / \mathrm{L}$ and changing the organic concentration. In various literatures, AGS has been reported as sludges larger than $0.2 \mathrm{~mm}$ [34-37]. The AGS used were those selected from ones cultured at laboratory-scale reactor to have size of over $0.2 \mathrm{~mm}$ ( $80 \mathrm{mesh} / 0.2 \mathrm{~mm}$ STS Sieve). The initial concentrations of mixed liquor suspended solids (MLSS), mixed liquor volatile suspended solids (MLVSS), and AGS were 2,430, 2,170, and 2,270 mg/L, respectively. The compositions during operation are shown in Table 1.

Table 1. Characteristics of the Influent

\begin{tabular}{|c|c|c|c|c|c|}
\hline \multirow{2}{*}{ Parameters } & \multirow{2}{*}{ Unit } & \multicolumn{4}{|c|}{ Influent } \\
\hline & & Min. & Max. & Average & S.D.* \\
\hline$(\mathrm{C} / \mathrm{N}: 5.0)$ & $(\mathrm{mg} / \mathrm{L})$ & 122.3 & 127.7 & 125.3 & 1.7 \\
\hline (C/N: 10.0) & & 247.3 & 254.3 & 250.6 & 1.9 \\
\hline${ }^{C U D} D_{\mathrm{Cr}} \quad(\mathrm{C} / \mathrm{N}: 15.0)$ & & 372.3 & 377.3 & 375.6 & 1.4 \\
\hline$(\mathrm{C} / \mathrm{N}: 20.0)$ & & 498.3 & 506.3 & 501.4 & 2.0 \\
\hline Total Nitrogen & $(\mathrm{mg} / \mathrm{L})$ & 23.6 & 25.6 & 25.1 & 0.3 \\
\hline Alkalinity & $(\mathrm{mg} / \mathrm{L})$ & 186.0 & 224.0 & 202.0 & 5.4 \\
\hline $\mathrm{pH}$ & - & 7.0 & 7.2 & 7.1 & 0.1 \\
\hline
\end{tabular}

${ }^{*}$ S.D.: Standard deviation

\subsection{Reactor and Experimental Set-up}

The reactor used was the sequencing batch reactor (SBR) reported to be preferable in forming and maintaining AGS [38-40], which hash effective volume of $5 \mathrm{~L}(155 \mathrm{~mm} \times 155 \mathrm{~mm} \times 222 \mathrm{~mm})$ and is made of acryl. The reactor was mounted with sampling port for collecting water and analysis and diffuser. The treated water was discharged through reactor middle port to apply volume exchange rate (VER) of 50\% [41-43]. The operational condition of SBR was fixed as 6 cycles, thus the hydraulic retention time (HRT) was set as $8 \mathrm{~h}$, to minimize the number of variables. The operation time of each phase were set as $10 \mathrm{~min}$ for filling and reaction, $210 \mathrm{~min}$ for aeration, $10 \mathrm{~min}$ for sedimentation, and 10 min for draw. The operation was performed by using programmable logic controller (PLC), a control program. The concentration of dissolved oxygen (DO) was maintained as $1.0-2.0 \mathrm{mg} / \mathrm{L}$ and the solid retention time (SRT) as 15-20 d. Table 2 shows the operation condition of the laboratory-scale SBR.

\subsection{Analytical Methods}

The chemical oxygen demand (COD) and total nitrogen (T-N) contents of the influent and treated water samples were analyzed using absorptiometry (DR-4000, Hach, USA) and the solids were analyzed using MLSS and MLVSS [44]. The sludge volume index $\left(\mathrm{SVI}_{30}\right)$ by change in $\mathrm{C} / \mathrm{N}$ ratio was measured to assess the sedimentation characteristics of AGS [45]. Increasing sludge ratio of less than $0.2 \mathrm{~mm}$ reduces pollutant treatment efficiency. Therefore, various studies have been reported highlighting the importance of increasing AGS ratio [29, 46, 47]. The AGS/MLSS ratio was measuring for those of over and under $0.2 \mathrm{~mm}$, separately, after collecting and selecting sludge (80 mesh/0.2 mm STS Sieve). The EPS contents of AGS were extracted using Formaldehyde and $\mathrm{NaOH}$ [48], and the extracted PN and PS were measured using Folin reagent [49] and Phenol-vitriol method [50]. The change in shape and surface characteristics of AGS were observed under the optical microscope (CX-31, Olympus, Japan) with magnitude of 40 after covering them with cover glass of $0.17 \mathrm{~mm}$.

\subsection{Microbial Community}

The microbial communities were carried out a total of two analyzes by collecting the initial sludge at the start of the experiment $(\mathrm{C} / \mathrm{N}$ ratio 5.0 conditions) and the sludge at the end of the experiment ( $\mathrm{C} / \mathrm{N}$ ratio 20.0). This experiment is composed of four phases. First, after completing sampling microorganism, DNA extraction (PowerMax® Soil DNA Isolation Kit) was performed and only DNA was measured using Fluorescence-based quantification technique of PicoGreen (Invitrogen, cat. \#P7589), (Pass criteria: sample with concentration of over $1.0 \mathrm{ng} / \mathrm{ul}$ ). Second, the library is fabricated by first PCR amplifying the target region and second one attaching the barcode (Nextra XT index kit). The main peak is checked again

Table 2. Experimental Conditions of Lab. Scale Reactor

\begin{tabular}{|c|c|c|c|c|c|c|}
\hline Vol. (L) & Flow (L/day) & Cycles/day & pH & HRT(h) & SRT (d) & Temp. $\left({ }^{\circ} \mathrm{C}\right)$ \\
\hline 5 & 15 & 6 & $7.0 \sim 7.2$ & 8 & $15 \sim 20$ & $23.8 \sim 24.2$ \\
\hline \multicolumn{7}{|c|}{$\begin{array}{l}\text { Operation time for } 1 \text { cycle }(\mathrm{min}): \text { Fill \& } \operatorname{React}(10) \rightarrow \operatorname{Oxic}(210) \rightarrow \operatorname{Settle}(10) \rightarrow \operatorname{Draw}(10) \\
\text { Influent } \mathrm{C} / \mathrm{N} \text { ratio }\left(\mathrm{mg} \mathrm{COD}_{\mathrm{Cr}} / \mathrm{mg} \mathrm{T}-\mathrm{N}\right): 5.0,10.0,15.0 \text { and } 20.0\end{array}$} \\
\hline
\end{tabular}


using chip photo and the Agilent Technologies 2100 Bioanalyzer to confirm the correct size of target. Third, the characterized samples were sequenced finally using sequencing by synthesis (SBS) technique of Illumina MiSeq ${ }^{\circledR}$ System. Fourth, the taxonomic assignment and statistical analysis were performed based on the sequencing date (Macrogen Inc., Seoul, Korea) [51-54].

\section{Results and Discussion}

\subsection{Reactor Performance}

The organic material removal efficiencies during whole operation period are shown in Fig. 1. The increase in $\mathrm{C} / \mathrm{N}$ ratio tended to lead to increase in removal efficiency where the average organic material removal efficiencies under $\mathrm{C} / \mathrm{N}$ ratios of 5.0, 10.0, 15.0, and 20.0 were $78.9,86.7,92.7$, and $95.9 \%$, respectively. It was intuitively confirmed, in particular, that the difference in removal efficiency between $\mathrm{C} / \mathrm{N}$ ratios 5.0 and 10.0 was large, and this tended to be stabilized under $\mathrm{C} / \mathrm{N}$ ratio of 10.0 and greater [55-57]. Kocaturk and Erguder [24] reported that the organic material removal efficiencies were kept over $90 \%$ under the conditions of higher $\mathrm{C} / \mathrm{N}$ ratio $(10,20$, and 30$)$ and kept low under the lower $\mathrm{C} / \mathrm{N}$ ratio, consistent with the results of this study. They explained that this is due to domination of heterotrophic bacteria, reporting that the wastewater with higher $\mathrm{C} / \mathrm{N}$ ratio is more appropriate for organic matter removal. Considering the result of this study, therefore, the gradual increase in organic matter removal efficiency is deemed to be result of domination of heterotrophic bacteria [58-60]. Choi [61], contrary the results of this study, reported that the organic matter removal efficiencies were 89.4-95.6\% under the $\mathrm{C} / \mathrm{N}$ ratio of under 2.0 using AGS. These high efficiency under lower $\mathrm{C} / \mathrm{N}$ ratio may be attributed to the high MLSS concentration $(8,000$ $\mathrm{mg} / \mathrm{L})$ compared to that of this study $(3,720 \mathrm{mg} / \mathrm{L})$.

The behavior of total nitrogen by change in $\mathrm{C} / \mathrm{N}$ ratio showed that the increase in $\mathrm{C} / \mathrm{N}$ ratio, as with organic matter removal efficiency, was related to increase in total nitrogen removal efficiency (Fig. 2). The total nitrogen removal efficiency of $57.5 \%$ under the lowest $\mathrm{C} / \mathrm{N}$ ratio, 5.0 , increased to $61.1,69.6$, and $79.1 \%$ for the $\mathrm{C} / \mathrm{N}$ ratios of 10.0, 15.0, and 20.0, respectively. The three reasons

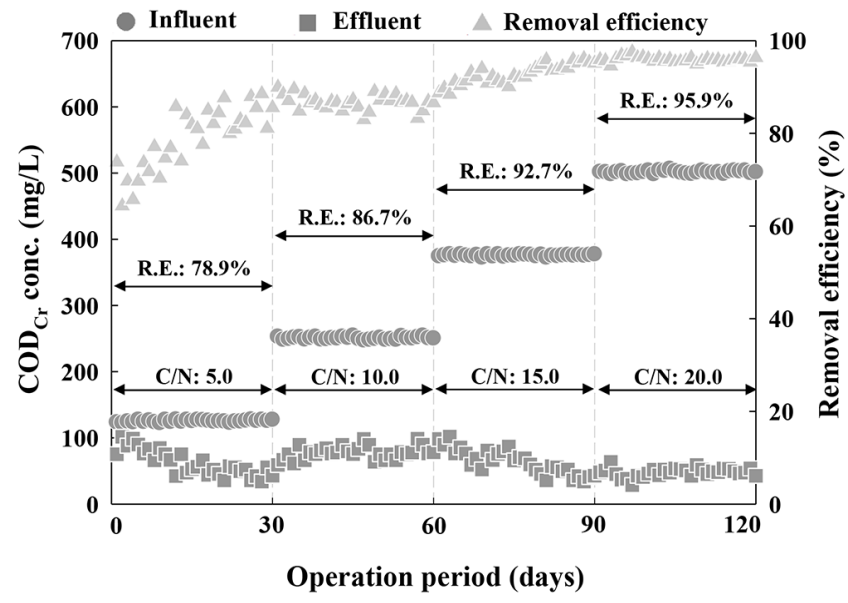

Fig. 1. Profile of $\mathrm{COD}_{\mathrm{Cr}}$ concentration at different $\mathrm{C} / \mathrm{N}$ ratio.

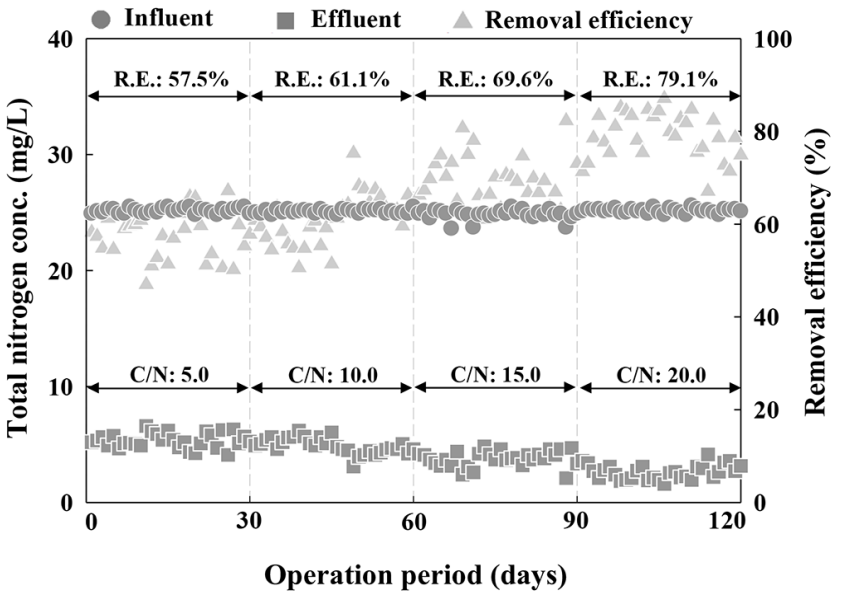

Fig. 2. Profile of total nitrogen concentration at different $\mathrm{C} / \mathrm{N}$ ratio.

of these increase in removal efficiency by increase in $\mathrm{C} / \mathrm{N}$ ratio despite the absence of anoxic reaction in whole processes are presented: denitrification reaction of nitrate nitrogen in the filling and reaction phase due to enough supply of organic matter needed for denitrification reaction; simultaneous nitrification and denitrification (SND) by AGS in the aeration reaction phase; the domination of aerobic or facultative anaerobes, which is described in the section 3.5 [62-64]. Mo et al. [29] emphasized the importance of controlling $\mathrm{C} / \mathrm{N}$ ratio since the total nitrogen removal efficiency decreased under $\mathrm{C} / \mathrm{N}$ of under 2.0. He et al. [65], to measure the nitrogen removal efficiency using AGS under the condition of low $\mathrm{C} / \mathrm{N}$ ratio (4.0), induced simultaneous nitrification and denitrification reaction through controlling size of aeration and reported that the removal efficiency of $62.74 \%$ under aeration size of $1.5 \mathrm{~L} / \mathrm{min}$ increased to $84.74 \%$ under that of $0.9 \mathrm{~L} / \mathrm{min}$. It means that the low removal efficiency observed under low $\mathrm{C} / \mathrm{N}$ ratio in this study may be increased by controlling the size of aeration, suggesting that flexible operation and control strategies are needed to increase the nitrogen removal efficiency.

\subsection{MLSS and $\mathrm{SVI}_{30}$}

Fig. 3 shows concentration of MLSS and AGS and behavior of AGS/MLSS ratio by condition. The initial concentration of MLSS and AGS and AGS/MLSS ratio were 2,430 mg/L, 2,270 mg/L and 93.4\%, respectively. After the operation, the MLSS and AGS, under the condition of $\mathrm{C} / \mathrm{N}$ ratio 5.0, tended to decrease down to 2,190 and $1,710 \mathrm{mg} / \mathrm{L}$ and accordingly the AGS/MLSS ratio to $78.1 \%$. These patterns were reversed when the $\mathrm{C} / \mathrm{N}$ ratio increased from 10.0 to 20.0, thus, the final values of them were $3,720 \mathrm{mg} / \mathrm{L}, 3,210$ $\mathrm{mg} / \mathrm{L}$, and $86.3 \%$. Kocaturk and Erguer [24] examined the effect of $\mathrm{C} / \mathrm{N}$ ratio $(7.5,5.0,3.5,2.0$, and 1.0) on the degradation of AGS and found that the decrease in $\mathrm{C} / \mathrm{N}$ ratio increased the degradation of granule. In addition, it is also reported that when the $\mathrm{C} / \mathrm{N}$ decreases from 7.5 to 5.0 , the granule collapses and the mean diameter decreases by $0.7 \mathrm{~mm}$. The decreased MLSS and AGS under relatively low $\mathrm{C} / \mathrm{N}$ ratio (5.0) observed in this study may be attributed to the leakage of sludge during granule degradation due to unbalance of $\mathrm{C} / \mathrm{N}$ ratio. Pijuan et al. [46] pointed out the importance of initial AGS/MLSS ratio for stable maintenance of AGS and Ni et al. [66] 


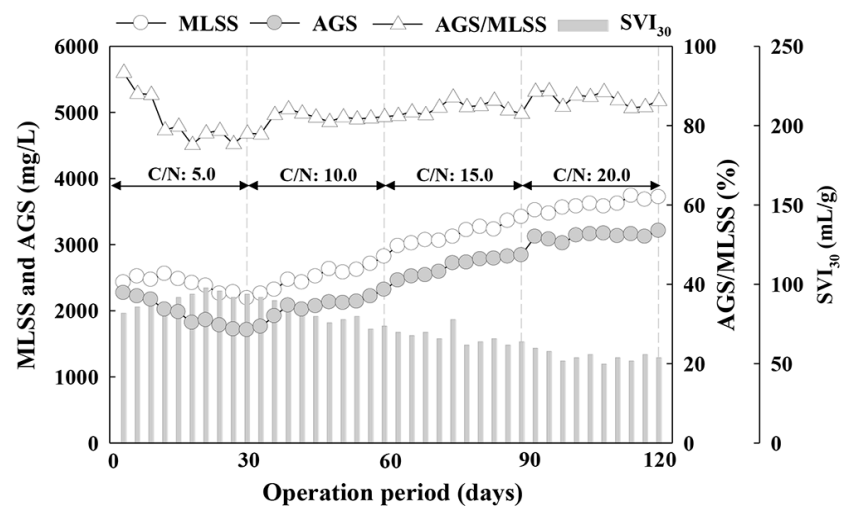

Fig. 3. Results of MLSS, AGS concentration, ACS/MLSS and SVI30 value at different $\mathrm{C} / \mathrm{N}$ ratio.

reported that the operation of over 300 days are needed to achieve AGS/MLSS ratio of $85 \%$. The results of this study demonstrated that the $\mathrm{C} / \mathrm{N}$ ratio, a factor described in Introduction to be influencing one of formation of AGS and it is suggested that the $\mathrm{C} / \mathrm{N}$ ratio of over 5.0 is necessary for maintenance of granule.

The sedimentation characteristics $\left(\mathrm{SVI}_{30}\right)$ of sludge showed similar pattern with the concentration of MLSS and AGS. SVI 30 , under $\mathrm{C} / \mathrm{N}$ ratio of 5.0, increased from $82 \mathrm{~mL} / \mathrm{g}$ of initial phase to 94 $\mathrm{mL} / \mathrm{g}$ gradually due to formation of sludge with relatively poor sedimentation, however, decreased gradually with the change of C/N ratio from 10.0 to 20.0 , reaching $54 \mathrm{~mL} / \mathrm{g}$ at the ending of operation. These relatively poor sedimentation may be explained by degradation of granule described in above paragraph, and the increase in $\mathrm{C} / \mathrm{N}$ ratio and the resultant increased portion of AGS is deemed to be reason of improved sedimentation. Wang et al. [67] performed low-strength wastewater treatment using AGS and found that at least $31 \mathrm{~d}$ are needed to achieve stable $\mathrm{SVI}_{30}$ after increase in initial phase. He et al. [68] reported the improved sludge concentration and sedimentation by decrease in aeration time. The maintenance of stable granule with excellent sedimentation by short sedimentation time (two minutes) was reported by $\mathrm{He}$ et al. [65].

\subsection{Extracellular Polymeric Substances Analysis}

The contents of PN, PS and PS/PN ratio showed different pattern with the increase in $\mathrm{C} / \mathrm{N}$ ratio (Fig. 4). The contents of total EPS increased from 118 to $172 \mathrm{mg} / \mathrm{g}$ MLVSS with the increase of $\mathrm{C} / \mathrm{N}$ from to 5.0 to 20.0, and the compose of PN and PS showed remarkable

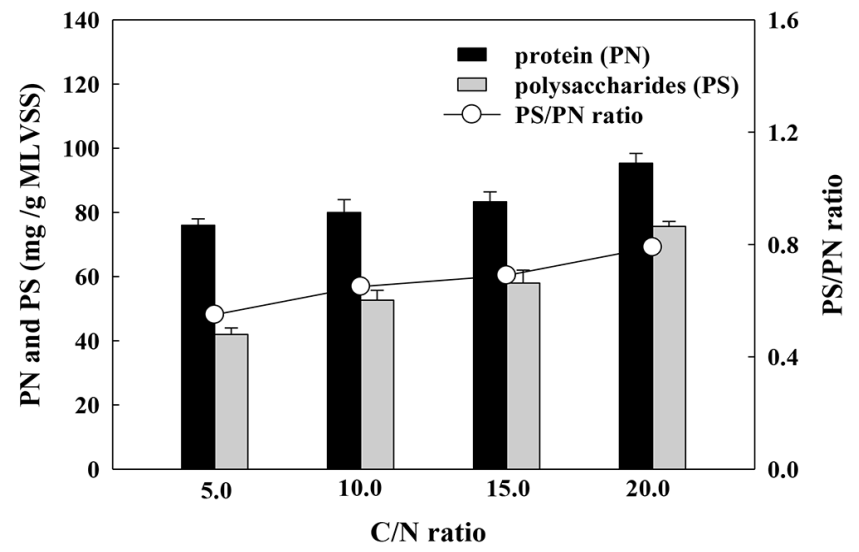

Fig. 4. Results of $P N, P S$ concentration and $P S / P N$ ratio value at different $\mathrm{C} / \mathrm{N}$ ratio.

difference in each $\mathrm{C} / \mathrm{N}$ ratio condition. The increase of PS from 42 to $76 \mathrm{mg} / \mathrm{g}$ MLVSS was stronger compared to those of PN from 76 to $96 \mathrm{mg} / \mathrm{g}$ MLVSS, and the resultant PS/PN ratio was shown to be 0.55 under condition of $\mathrm{C} / \mathrm{N}$ ratio 5.0 and 0.79 under $\mathrm{C} / \mathrm{N}$ ratio 20.0. The EPS was reported as importance factor in determining the formation and stability of AGS in many studies [69-71] and the contents of PS tended to be high in stable granule [72-74], consistent with this study showing increase in PS under high $\mathrm{C} / \mathrm{N}$ ratio condition. The results of this study demonstrated that the gradual increase in $\mathrm{C} / \mathrm{N}$ ratio has direct effects on the stability of AGS and also on the contents of PS, a constituent of EPS, making preferable condition for maintenance and stability of granule.

\subsection{Microscopic Observation of AGS}

Fig. 5 shows the observation, using optical microscope, of AGS under each condition. The hair-like objects of surface and filamentous fungus were more commonly observed in $\mathrm{C} / \mathrm{N} 5.0$ conditions than any other ones [75, 76]. The growth of the filamentous fungus has been reported to be observed in activated sludge and AGS and the sludge bulking has been pointed as a reason [77-79]. These results may be also explained by decrease in MLSS and the relatively small size of fungus in low $\mathrm{C} / \mathrm{N}$ ratio condition is deemed to be due to decrease in AGS/MLSS ratio. Under the $\mathrm{C} / \mathrm{N}$ ratio over 10.0, the size of fungus became bigger, reaching up to $1.0 \mathrm{~mm}$ and the shape was circular and dense. The degradation of granule in this study occurred more commonly in lower $\mathrm{C} / \mathrm{N}$
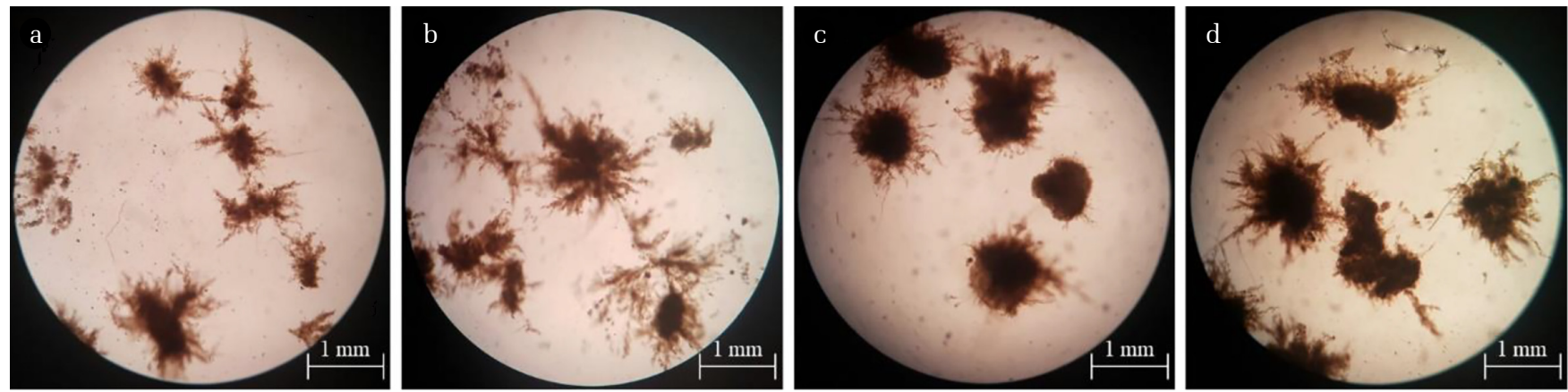

Fig. 5. Morphology observation of $\mathrm{AGS}$ at different $\mathrm{C} / \mathrm{N}$ ratio, (a) 5.0; (b) 10.0; (c) 15.0; (d) 20.0 (40 magnification by optical microscope). 
ratio, directly and indirectly confirming the importance of $\mathrm{C} / \mathrm{N}$ ratio in stability of granule. It is recommended for future studies to investigate the $\mathrm{C} / \mathrm{N}$ ratio controlling method (such as external carbon source) and operation method for stability of granule.

\subsection{Microbial Communities of AGS}

The operational taxonomic unit (OTU) of initial and end phases of experiment were 755 and 158, respectively, showing the decrease in diversity of microorganism. These may be explained by the gradual domination of heterotrophic bacteria that had adopted to microorganism degradation with the gradual increase in $\mathrm{C} / \mathrm{N}$ ratio, decreasing the richness and diversity of microorganism [80-82]. The results of pyrosequencing analysis of microorganism

\section{a}
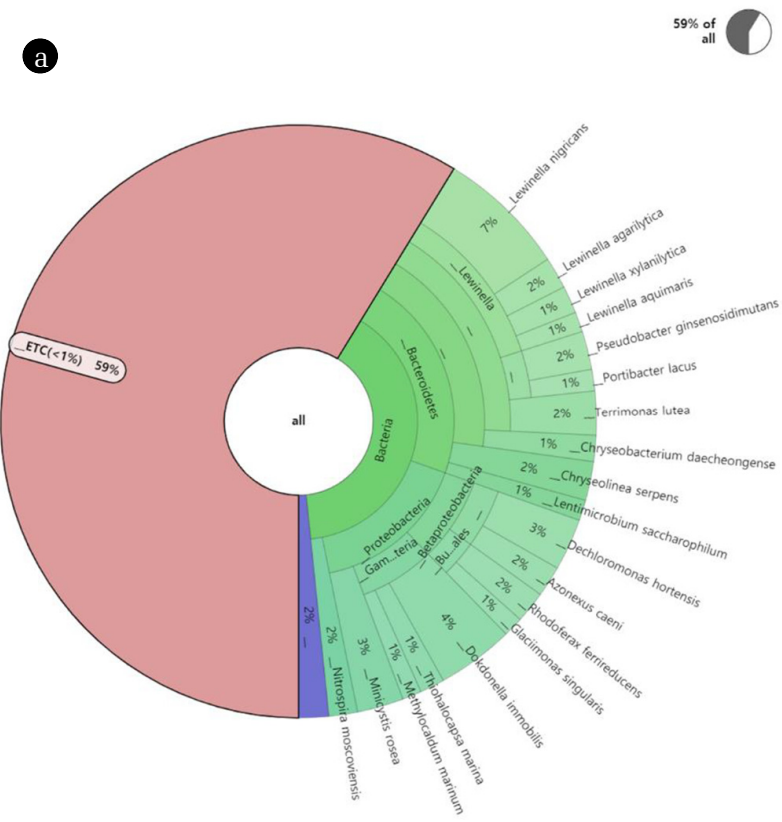

\section{b}

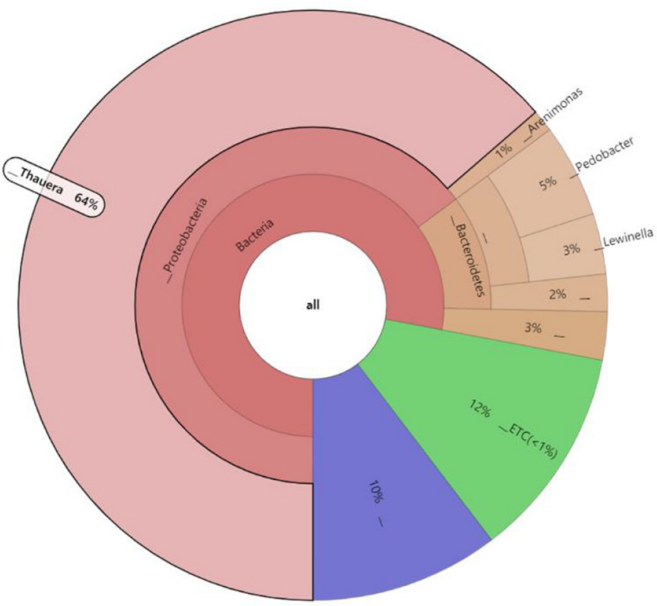

Fig. 6. Results of microbial communities using dynamic pie chart (Krona). (a) Initial phase AGS and (b) End phase AGS. community of AGS, using the dynamic pie chart (krona), at initial and end phases showed difference between them (Fig. 6). The Proteobacteria reported to be most rich in the process of wastewater treatment under phylum condition were shown to be 34.8 and $70.2 \%$, respectively, a highest increasing rate [83, 84]. These in Bacteroidetes were 37.4 and $10.9 \%$, respectively, indicating decrease in the proportion. The Bacteroidetes, as with Firmicutes, was reported to show strong domination under condition of high salinity [85-88].

In terms of genus, Thauera occupied $0.01 \%$ in initial phase, however, increased to $63.7 \%$ in end phase, becoming most common one. Thauera is regarded as very important microorganism in the process of wastewater treatment [89], as aerobic denitrification one [90, 91], and as one contributing to improved production of EPS including AGS of microorganism [92-94]. The domination of Thauera, therefore, is suggested to be and explanation of the results of this study such as increase in organic material in AGS and improvement of denitrification efficiency and contents of EPS with increase in C/N ratio. The proportion of Pedobacter, knows as aerobic or microaerobic [95] and Lewinella known as organic chemical heterotrophic microorganism [96] were, at ending phase, 5.1 and 3.3\%, respectively.

\section{Conclusions}

A study on nutrient salt removal efficiency and stability of AGS in various $\mathrm{C} / \mathrm{N}$ ratio conditions was performed. The increase in $\mathrm{C} / \mathrm{N}$ ratio from 5.0 to 20.0 increased the organic matter and nitrogen removal efficiency to 95.9 and $79.1 \%$, respectively. MLSS and AGS tended to decrease under the $\mathrm{C} / \mathrm{N}$ ratio of 5.0 , however, increased under $\mathrm{C} / \mathrm{N}$ ratio up to 20.0 , reaching 3,720 and $3,210 \mathrm{mg} / \mathrm{L}$ in ending phase, resulting in AGS/MLSS ratio of $86.3 \%$. The change in $\mathrm{SVI}_{30}$ showed similar pattern with MLSS where the value decreased from 82 to $54 \mathrm{~mL} / \mathrm{g}$ under low C/N ratio. For the EPS contents, an influencing factor of granule stability, the PS/PN ratio increased from 0.55 to 0.79 . The microscope observation showed more clear circular shape of sludge with the increase in $\mathrm{C} / \mathrm{N}$ ratio. For the microbial community, the Thauera was the most common genus in ending phase occupying $63.7 \%$. The gradual increase in $\mathrm{C} / \mathrm{N}$ ratio, therefore, was confirmed to maintain the AGS stably in the operation of AGS-based biological treatment system by making heterotrophic bacteria (Thauera) as dominant. It is considered that the future studies are needed to examine the controlling of operation condition of AGS-based process and measurement of stability by using real wastewater with various $\mathrm{C} / \mathrm{N}$ ratio.

\section{Acknowledgment}

This subject is supported by Korea Ministry of Environment as "Global Top Project" (Project No.:2016002190006).

\section{Author Contributions}

H.G.K. (Ph. D.) conducted all the experiments. J.T.K. (Professor) and D.H.A (Professor) wrote the manuscript. 


\section{References}

1. Kent TR, Bott CB, Wang ZW. State of the art of aerobic granulation in continuous flow bioreactors. Biotechnol. Adv. 2018;36: 1139-1166.

2. Ren X, Chen Y, Guo, L, et al. The influence of $\mathrm{Fe}^{2+}, \mathrm{Fe}^{3+}$ and magnet powder $\left(\mathrm{Fe}_{3} \mathrm{O}_{4}\right)$ on aerobic granulation and their mechanisms. Ecotoxicol. Environ. Saf. 2018;164:1-11.

3. Khan MF, Yu L, Tay JH, Achari G. Coaggregation of bacterial communities in aerobic granulation and its application on the biodegradation of sulfolane. J. Hazard. Mater. 2019;377:206-214.

4. Jahn L, Svardal K, Krampe J. Comparison of aerobic granulation in SBR and continuous-flow plants. J. Environ. Manage. 2019;231:953-961.

5. Wang Z, Gao M, She Z, et al. Effects of salinity on performance, extracellular polymeric substances and microbial community of an aerobic granular sequencing batch reactor. Sep. Purif. Technol. 2015;144:223-231.

6. Wei D, Wang Y, Wang X, et al. Toxicity assessment of 4-chlorophenol to aerobic granular sludge and its interaction with extracellular polymeric substances. J. Hazard Mater. 2015;289: 101-107.

7. Cai W, Jin M, Zhao Z, et al. Influence of ferrous iron dosing strategy on aerobic granulation of activated sludge and bioavailability of phosphorus accumulated in granules. Bioresour. Technol. Rep. 2018;2:7-14.

8. Carrera P, Campo R, Méndez R, et al. Does the feeding strategy enhance the aerobic granular sludge stability treating saline effluents? Chemosphere 2019;226:865-873.

9. Caluwé M, Dobbeleers T, D’aes J, et al. Formation of aerobic granular sludge during the treatment of petrochemical wastewater. Bioresour. Technol. 2017;238:559-567.

10. Ren Y, Ferraz F, Lashkarizadeh M, Yuan Q. Comparing young landfill leachate treatment efficiency and process stability using aerobic granular sludge and suspended growth activated sludge. J. Water Proc. Eng. 2017;17:161-167.

11. Corsino SF, di Biase A, Devlin TR, Munz G, Torregrossa M, Oleszkiewicz JA. Effect of extended famine conditions on aerobic granular sludge stability in the treatment of brewery wastewater. Bioresour. Technol. 2017;226:150-157.

12. Vashi H, Iorhemen OT, Tay JH. Degradation of industrial tannin and lignin from pulp mill effluent by aerobic granular sludge technology. J. Water Proc. Eng. 2018;26:38-45.

13. Zhang D, Li W, Hou C, et al. Aerobic granulation accelerated by biochar for the treatment of refractory wastewater. Chem. Eng. J. 2017;314:88-97.

14. Hamza RA, Sheng Z, Iorhemem OT, Zaghloul MS, Tay JH. Impact of food-to-microorganisms ratio on the stability of aerobic granular sludge treating high-strength organic wastewater. Water Res. 2018;147:287-298.

15. Long B, Xuan X, Yang C, Zhang L, Cheng Y, Wang J. Stability of aerobic granular sludge in a pilot scale sequencing batch reactor enhanced by granular particle size control. Chemosphere 2019;225:460-469.

16. Yuan Q, Gong H, Xi H, et al. Strategies to improve aerobic granular sludge stability and nitrogen removal based on feeding mode and substrate. J. Environ. Sci. 2019;84:144-154.
17. Zhang Z, Cao R, Jin L, et al. The regulation of N-acyl-homoserine lactones (AHLs)-based quorum sensing on EPS secretion via ATP synthetic for the stability of aerobic granular sludge. Sci. Total Environ. 2019;673:89-91.

18. Wu L, Peng CY, Peng YZ, Li LY, Wang SY, Ma Y. Effect of wastewater $\mathrm{COD} / \mathrm{N}$ ratio on aerobic nitrifying sludge granulation and microbial population shift. J. Environ. Sci. 2012;24:234-241.

19. Wang H, Song Q, Wang J, et al. Simultaneous nitrification, denitrification and phosphorus removal in an aerobic granular sludge sequencing batch reactor with high dissolved oxygen: Effects of carbon to nitrogen ratios. Sci. Total Environ. 2018;642:1145-1152.

20. Hamza RA, Zaghloul MS, Iorhemem OT, Sheng Z, Tay JH Optimization of organics to nutrients (COD:N:P) ratio for aerobic granular sludge treating high-strength organic wastewater. Sci. Total Environ. 2019;650:3168-3179.

21. Yang SF, Tay JH, Liu Y, Effect of substrate nitrogen/chemical oxygen demand ratio on the formation of aerobic granules. J. Environ. Eng. 2005;131:86-92.

22. Wu L, Peng C, Peng Y, Li L, Wang S, Ma Y. Effect of wastewater $\mathrm{COD} / \mathrm{N}$ ratio on aerobic nitrifying sludge granulation and microbial population shift. J. Environ. Sci. 2012;24:234-241.

23. Luo J, Hao T, Wei L, Mackey HR, Lin Z, Chen GH. Impact of influent $\mathrm{COD} / \mathrm{N}$ ratio on disintegration of aerobic granular sludge. Water Res. 2014;62:127-135.

24. Kocaturk I, Erguder TH. Influent COD/TAN ratio affects the carbon and nitrogen removal efficiency and stability of aerobic granules. Ecol. Eng. 2016;90:12-24.

25. Liu YQ, Liu Y, Tay JH, The effects of extracellular polymeric substances on the formation and stability of biogranules. Appl. Microbiol. Biotechnol. 2004;65:143-148.

26. Zhu L, Lv ML, Dai X, Yu YW, Qi HY, Xu XY. Role and significance of extracellular polymeric substances on the property of aerobic granule. Bioresour. Technol. 2012;107:46-54.

27. Corsino SF, Capodici M, Torregrossa M, Viviani G. Physical properties and Extracellular Polymeric Substances pattern of aerobic granular sludge treating hypersaline wastewater, Bioresour. Technol. 2017;229:152-159.

28. de Graaff DR, Felz S, Neu TR, Pronk M, van Loosdrecht MCM, Lin Y. Sialic acids in the extracellular polymeric substances of seawater-adapted aerobic granular sludge. Water Res. 2019; 155:343-351.

29. Mo WJ, Kim HY, Choi HN. The operation characteristics of advanced sewage treatment process using aerobic granular sludge in pilot plant. J. Korean Soc. Environ. Eng. 2019;41:61-68.

30. Yae JB, Ryu JH, Tuyen NV, Kim HG, Hong SW, Ahn DH. An aerobic granular sludge process for treating low carbon/nitrogen ratio sewage. Environ. Eng. Res. 2019;24:238-245.

31. de Sousa Rollemberg SL, de Oliveira LQ, Barros ARM, Melo VMM, Firmino PIM, dos Santos AB. Effects of carbon source on the formation, stability, bioactivity and biodiversity of the aerobic granule sludge. Bioresour. Technol. 2019;278:195-204.

32. MOE. 2017 Statistics of sewerage [Internet]. Ministry of Environment Republic of Korea; [cited 7 February 2019]. Available from: http://www.me.go.kr

33. MOE. 2017 Status of public wastewater treatment facilities [Internet]. Ministry of Environment Republic of Korea; [cited 
4 January 2019]. Available from: http://www.me.go.kr

34. Nancharaiah YV, Reddy GKK. Aerobic granular sludge technology: Mechanisms of granulation and biotechnological applications. Bioresour. Technol. 2018;247:1128-1143.

35. van Dijk EJH, Pronk M, van Loosdrecht MCM. Controlling effluent suspended solids in the aerobic granular sludge process. Water Res. 2018;147:50-59.

36. Yang B, Wang M, Wang J, et al. Mechanism of high contaminant removal performance in the expanded granular sludge blanket (EGSB) reactor involved with granular activated carbon for low-strength wastewater treatment. Chem. Eng. J. 2018;334: 1176-1185.

37. Chen G, Bin L, Tang B, et al. Rapid reformation of larger aerobic granular sludge in an internal-circulation membrane bioreactor after long-term operation: Effect of short-time aeration. Bioresour. Technol. 2019;273:462-467.

38. Arrojo B, Mosquera-Corral A, Garrido JM, Mendez R. Aerobic granulation with industrial wastewater in sequencing batch reactors. Water Res. 2004;38:3389-3399.

39. Wang SG, Liu, XW, Gong WX, Gao BY, Zhang DH, Yu HQ. Aerobic granulation with brewery wastewater in a sequencing batch reactor. Bioresour. Technol. 2007;98:2142-2147.

40. Kishida N, Tsuneda J, Kim JH, Sudo R. Simultaneous nitrogen phosphorus removal from high-strength industrial wastewater using aerobic granular sludge. J. Environ. Eng. 2009;135: 153-158.

41. Su KZ, Ni BJ, Yu HQ. Modeling and optimization of granulation process of activated sludge in sequencing batch reactors. Biotechnol. Bioeng. 2013;110:1312-1322.

42. Szabó E, Hermansson M, Modin O, Persson F, Wilén BM. Effects of wash-out dynamics on nitrifying bacteria in aerobic granular sludge during start-up at gradually decreased settling time. Water 2016;8:172.

43. de Sousa Rollemberg SL, Barros ARM, Firmino PIM, dos Santos AB. Aerobic granular sludge: Cultivation parameters and removal mechanisms. Bioresour. Technol. 2018;270:678-688.

44. APHA (American Public Health Association). Standard methods for the examination of water and wastewater. Washington D.C.:APHA; 2008.

45. Campo R, Corsino SF, Torregrossa M, Bella GD. The role of extracellular polymeric substances on aerobic granulation with stepwise increase of salinity. Sep. Purif. Technol. 2018;195: 12-20.

46. Pijuan M, Werner U, Yuan Z. Reducing the startup time of aerobic granular sludge reactors through seeding floccular sludge with crushed aerobic granules. Water Res. 2011;45: 5075-5083.

47. Kim HG, Ahn DH, Effects on the stability of aerobic granular sludge (AGS) at different carbon/nitrogen ratio. J. Environ. Sci. Int. 2019;28:719-727.

48. Liu H, Fang HHP. Extraction of extracellular polymeric substances (EPS) of sludges. J. Biotechnol. 2002;95:249-256.

49. Lowry OH, Rosebrough NJ, Farr AL, Randall RJ. Protein measurement with the Folin phenol reagent. J. Biol. Chem. 1951;193:265-275.

50. Herbert D, Philipps PJ, Strange RE. Carbohydrate analysis. Methods Enzymol. B. 1971;5:265-277.
51. Hwang IW, Kwon BN, Kim HJ, et al. Assessment of associations between mitochondrial DNA haplogroups and attention deficit and hyperactivity disorder in Korean children. Mitochondrion 2019;47:174-178.

52. Kraychete GB, Campana EH, Picão RC, Bonelli RR. qnrD-harboring plasmids in Providencia spp. recovered from food and environmental Brazilian sources. Sci. Total Environ. 2019;646: 1290-1292.

53. Cho KJ, Seo KW, Shin SG, Lee SH, Park CH. Process stability and comparative rDNA/rRNA community analyses in an anaerobic membrane bioreactor with silicon carbide ceramic membrane applications. Sci. Total Environ. 2019;666:155-164.

54. Kraberger S, Cook CN, Schmidlin K, et al. Diverse single-stranded DNA viruses associated with honey bees (Apis mellifera). Infect. Genet. Evol. 2019;71:179-188.

55. Lin J, Zhang P, Li G, Yin J, Li J, Zhao X. Effect of COD/N ratio on nitrogen removal in a membrane-aerated biofilm reactor. Int. Biodeter. Biodegr. 2016;113:74-79.

56. Li J, Meng J, Li J, et al. The effect and biological mechanism of COD/TN ratio on nitrogen removal in a novel upflow microaerobic sludge reactor treating manure-free piggery wastewater. Bioresour. Technol. 2016;209:360-368.

57. Yadu A, Sahariah BP, Anandkumar J. Influence of COD/ammonia ratio on simultaneous removal of $\mathrm{NH}_{4}{ }^{+}-\mathrm{N}$ and COD in surface water using moving bed batch reactor. J. Water Process Eng. 2018;22:66-72.

58. Zhang $\mathrm{X}$, Zhang $\mathrm{H}$, Ye C, Wei $\mathrm{M}$, Du J. Effect of COD/N ratio on nitrogen removal and microbial communities of CANON process in membrane bioreactors. Bioresour. Technol. 2015;189: 302-308.

59. Ji G, Zhi W, Tan Y. Association of nitrogen micro-cycle functional genes in subsurface wastewater infiltration systems. Ecol. Eng. 2012;44:269-277.

60. Zhi W, Ji G. Quantitative response relationships between nitrogen transformation rates and nitrogen functional genes in a tidal flow constructed wetland under $\mathrm{C} / \mathrm{N}$ ratio constraints. Water Res. 2014;64:32-41.

61. Choi SW. Bio-kinetic and design analysis of a sequencing batch reactor by aerobic granular sludge. J. Korean Soc. Environ. Eng. 2011;33:275-280.

62. Deng L, Ngo HH, Guo W, Wang J, Zhang H. Evaluation of a new sponge addition-microbial fuel cell system for removing nutrient from low $\mathrm{C} / \mathrm{N}$ ratio wastewater. Chem. Eng. J. 2018;338:166-175.

63. Zhou X, Zhang Z, Zhang X, Liu Y. A novel single-stage process integrating simultaneous COD oxidation, partial nitritation-denitritation and anammox (SCONDA) for treating ammonia-rich organic wastewater. Bioresour. Technol. 2018;254:50-55.

64. Chai H, Xiang Y, Chen R, et al. Enhanced simultaneous nitrification and denitrification in treating low carbon-to-nitrogen ratio wastewater: Treatment performance and nitrogen removal pathway. Bioresour. Technol. 2019;280:51-58.

65. He Q, Chen L, Zhang S, Chen R, Wang H. Hydrodynamic shear force shaped the microbial community and function in the aerobic granular sequencing batch reactors for low carbon to nitrogen $(\mathrm{C} / \mathrm{N})$ municipal wastewater treatment. Bioresour. Technol. 2019;271:48-58. 
66. Ni BJ, Xie WM, Liu SG, et al. Granulation of activated sludge in a pilot-scale sequencing batch reactor for the treatment of low-strength municipal wastewater. Water Res. 2009;43: 751-761.

67. Wang Q, Yao R, Yuan Q, et al. Aerobic granules cultivated with simultaneous feeding/draw mode and low-strength wastewater: Performance and bacterial community analysis. Bioresour. Technol. 2018;261:232-239.

68. He Q, Chen L, Zhang S, et al. Simultaneous nitrification, denitrification and phosphorus removal in aerobic granular sequencing batch reactors with high aeration intensity: Impact of aeration time. Bioresour. Technol. 2018;263:214-222.

69. Sheng GP, Yu HQ, Li XY. Extracellular polymeric substances (EPS) of microbial aggregates in biological wastewater treatment systems: a review. Biotechnol. Adv. 2010;28:882-894.

70. Guo WS, Ngo HH, Li JX. A mini-review on membrane fouling. Bioresour. Technol. 2012;122:27-34.

71. Wang S, Ma X, Wang Y, Du G, Tay JH, Li J. Piggery wastewater treatment by aerobic granular sludge: Granulation process and antibiotics and antibiotic-resistant bacteria removal and transport. Bioresour. Technol. 2019;273:350-357.

72. Tay JH, Liu QS, Liu Y. Microscopic observation of aerobic granulation in sequential aerobic sludge blanket reactor. J. Appl. Microbiol. 2001;91:168-175.

73. Zhang LL, Feng XX, Zhu NW, Chen JM. Role of extracellular protein in the formation and stability of aerobic granules. Enzym. Microb. Technol. 2007;41:551-557.

74. Liu J, Li J, Xie K, Sellarmuthu B. Role of adding dried sludge micropowder in aerobic granular sludge reactor with extended filamentous bacteria. Bioresour. Technol. Rep. 2019;5:51-58.

75. Martins AMP, Pagilla K, Heijnen JJ, van Loosdrecht MCM. Filamentous bulking sludge - a critical review. Water Res. 2004;38:793-817.

76. Liu Y, Liu QS. Research and implementation of 3D assembly animate based on B/S structure. Biotechnol. Adv. 2006;24: 115-117.

77. Tay JH, Liu QS, Liu Y. Microscopic observation of aerobic granulation in sequential aerobic sludge blanket reactor. J. Appl. Microbiol. 2001;91:168-175.

78. Guo J, Peng Y, Wang S, Yang X, Yuan Z. Filamentous and non-filamentous bulking of activated sludge encountered under nutrients limitation or deficiency conditions. Chem. Eng. J. 2014;255:453-461.

79. Deepnarain N, Nasr M, Kumari S, et al. Decision tree for identification and prediction of filamentous bulking at full-scale activated sludge wastewater treatment plant. Process Saf. Environ. Prot. 2019;126:25-34.

80. Zhao Y, Huang J, Zhao H, Yang H. Microbial community and $\mathrm{N}$ removal of aerobic granular sludge at high COD and $\mathrm{N}$ loading rates. Bioresour. Technol. 2013;143:439-446.

81. Zhao YG, Huang J, Zhao H, Yang H. Microbial community and $\mathrm{N}$ removal of aerobic granular sludge at high COD and N loading rates. Bioresour. Technol. 2013;143:439-446.

82. Lv Y, Wan C, Lee DJ, Liu X, Tay JH. Microbial communities of aerobic granules: Granulation mechanisms. Bioresour. Technol. 2014;169:344-351.

83. Zhang T, Shao MF, Ye L. 454 Pyrosequencing reveals bacterial diversity of activated sludge from 14 sewage treatment plants. ISME J. 2012;6:1137-1147.

84. Liao R, Li Y, Wang Z, et al. 454 pyrosequencing analysis on microbial diversity of an expanded granular sludge bed reactor treating high $\mathrm{NaCl}$ and nitrate concentration wastewater. Biotechnol. Bioproc. Eng. 2014;19:183-190.

85. He H, Chen Y, Li X, Cheng Y, Yang C, Zeng G. Influence of salinity on microorganisms in activated sludge processes: A review. Int. Biodeterior. Biodegradation 2017;119:520-527.

86. Zhang Y, Jiang WL, Xu RX, Wang GX, Xie B. Effect of short-term salinity shock on unacclimated activated sludge with pressurized aeration in a sequencing batch reactor. Separ. Purif. Technol. 2017;178:200-206.

87. Chen Y, He H, Liu H, et al. Effect of salinity on removal performance and activated sludge characteristics in sequencing batch reactors. Bioresour. Technol. 2018;249:890-899.

88. Corsino SF, Capodici M, Pippo FD, Tandoi V, Torregrossa M. Comparison between kinetics of autochthonous marine bacteria in activated sludge and granular sludge systems at different salinity and SRTs. Water Res. 2019;148:425-437.

89. Liu BB, Zhang F, Feng XX, et al. Thauera and Azoarcus as functionally important genera in a denitrifying quinoline-removal bioreactor as revealed by microbial community structure comparison. FEMS Microbiol. Ecol. 2006;55:274-286.

90. Foss S, Harder J. Thauera linaloolentis sp. nov. and Thauera terpenica sp. nov., isolated on oxygen-containing monoterpenes (linalool, menthol, and eucalyptol and nitrate). Syst. Appl. Microbiol. 1998;21:365-373.

91. Scholten E, Lukow T, Auling G, Kroppenstedt RM, Rainey FA, Diekmann H. Thauera mechernichensis sp. nov., an aerobic denitrifier from a leachate treatment plant. Int. J. Syst. Evol. Bacteriol. 1999;49:1045-1051.

92. Pollock TJ, van Workum WAT, Thorne L, et al. Assignment of biochemical functions to glycosyl transferase genes which are essential for biosynthesis of exopolysaccharides in Sphingomonas strain S88 and Rhizobium leguminosarum. J. Bacteriol. 1998;180:586-593.

93. Allen MS, Welch KT, Prebyl BS, Baker DC, Meyers AJ, Sayler GS. Analysis and glycosyl composition of the exopolysaccharide isolated from the floc-forming wastewater bacterium Thauera sp. MZ1T. Environ. Microbiol. 2004;6:780-790.

94. Cydzik-Kwiatkowska A. Bacterial structure of aerobic granules is determined by aeration mode and nitrogen load in the reactor cycle. Bioresour. Technol. 2015;181:312-320.

95. Moreira IS, Amorim CL, Ribeiro AR, et al. Removal of fluoxetine and its effects in the performance of an aerobic granular sludge sequential batch reactor. J. Hazard. Mater. 2015;287:93-101.

96. Wan X, Gao M, Ye M, et al. Formation, characteristics and microbial community of aerobic granular sludge in the presence of sulfadiazine at environmentally relevant concentrations. Bioresour. Technol. 2018;250:486-494. 